\title{
仮性同色表（程度判定表）の評価
}

\author{
石黒 進・秋山 真紀・田辺 詔子・深見嘉一郎 \\ 名古屋第一赤十字病院 \\ 視覚研究所
}

\section{Evaluation of Pseudoisochromatic Plates for Grading}

\author{
Susumu Ishiguro, Maki Akiyama, Shoko Tanabe, Kaitiro Hukami
}

Japanese Red Cross Nagoya First Hospital

Institute of Visual Science

要 約

先天色覚異常者886名に対しては東京医科大学式色覚検查表（以下, TMC表）と石原・大熊表の 成績から，またこの集団とは重複しない別の先天色覚異常者1000名に対しては国際版石原式色覚検 查表 (以下, 石原表) の分類表（程度判定もかねる）の成績から, 仮性同色表による程度判定の妥 当性を検討した。

TMC表では二色型色覚（色盲）の $20.1 \%$ 中等度または弱度と判定された。一方, 異常三色型色

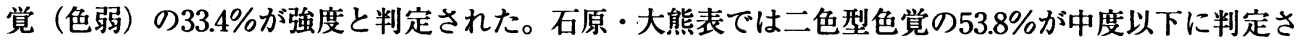
れ, 異常三色型色覚の $10.9 \%$ が強度と判定された。石原表では全体の $85.9 \%$ 色盲 (強度) と判定さ れた。また，TMC表と石原・大熊表の二つの表で判定結果が一致する場合は少なかった。

この様に, 仮性同色表による判定は実際の程度を示さない場合が多い。その理由として, 程度表 に使用されている色（地色と図形色）の色差が色覚異常者の異常の程度を判定するうえで適切では ないためであることを, FarnsworthのUniform Chromaticity Scale Diagram (UCSD) ${ }^{1}$ によって説明 した。

\section{Abstract}

In order to evaluate the validity of grading plated, the results of the TMC Plates and Ishihara Okuma Plates of 886 subjects, and those of the Ishihara tests of 1,000 subjects were reviewed. Color vision defects of all the subjects were diagnosed with a battery of color vision tests including anomaloscope. With the TMC Plates, $20.1 \%$ of dichromats scored moderate or mild degree and $33.4 \%$ of anomalous trichromats scored high degree. With the Ishihara-Okuma Plates, $53.8 \%$ of dichromats scored moderate or mild degree and $\mathbf{1 0 . 8 \%}$ of anomalous trichromats scored high degree. In each subject, diagnoses of two plates were often different. With the Ishihara test, $85.9 \%$ of anomalous trichromats were judged to be dichromats. Thus, results of grading plates are rather inconsistent with real degrees of color vision defects. The reason of such inconsistency is well explained when the colors used in the plates are plotted on Fransworth's Uniform Chromaicity Scale Diagram.

連絡先（厂453）名古屋市中村区道下町 $3-35$

名古屋第一赤十字病院 眼科 石 黒 進

Tel. $052-481-5111$

Key words : congenital color vision defect, pseudoisochromatic plates, degree of color vision defect 


\section{I．緒言}

一口に色覚異常と言っても，その中には正常 者とほとんど大差のない軽度のものから, 信号 灯の色が容易に判別出来ないほどの強度の色覚 異常まで色々ある。これらを全く同じ「色覚異 常」とまとめてしまうことは問題である。個々 の色覚異常者の程度をしっかり把握し, それに 応じての職業適性や日常生活の注意に関する指 導・助言が行われることが大切である。そこで, 仮性同色表には程度判定用の表が含まれている ものが多いので, それらによって程度判定が出 来るかを検証してみた。

\section{II . 対象及び方法}

先天色覚異常者886名 (A群) とこの集団とは 重複しない先天色覚異常者1000名（B群）の二 つの集団について検討した。A群とB群のアノマ ロスコープによる病型分類は表 1 に示す通りで あった。

表 1. 対象とした先天色覚異常の病型分類

\begin{tabular}{|c|c|c|}
\hline & A 舴 & B 群 \\
\hline 第一色高 & 100 & 89 \\
\hline 第二色亩 & 298 & 242 \\
\hline 第一色㽗 & 137 & 144 \\
\hline 策二色䎳 & 351 & 525 \\
\hline 合計 & 886 & 1000 \\
\hline
\end{tabular}

A群では東京医科大学式色覚検查表（以下, TMC表）と石原・大熊表の成績，B群では国際 版石原式色覚検查表（以下，石原表）の成績を 検討した。判定基準は，それぞれ各表に規定さ れた通りに行った。すなわち，TMC表では，程 度表の二つある数字が両方読めれば弱度, 左の 数字が読めて, 右の数字が読めなければ中等度, 両方読めなければ強度である。石原・大熊表で は，誤りのないものは微度，V 表またはV表の みの誤りは軽度, III 表またはIV 表の誤りは中度, I 表または II 表の誤りは強度である。石原表で
は，二つある数字が両方読めなければ赤緑色盲 (強度)，一数字だけ読めるものは赤緑色弱（軽 度）と以前程度表としても使われていたのでこ の分類で検証した。石原・大熊表と石原表では 第一異常と第二異常の分類も同時に判定される が，それはここではふれない。

\section{III. 結 果}

これらの仮性同色表による色覚異常者の程度 判定結果は以下のようになった。

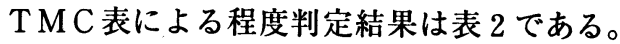
二色型色覚（いわゆる色盲）は, 強度, 異常三 色型色覚（いわゆる色弱）は中等度または弱度 と判定されるのが妥当であるが, 異常三色型色 覚で強度と判定された者が163名 (33.4\%) と約 $1 / 3$ いた。

石原・大熊表による程度判定結果は表 3 であ る。強度と判定された異常三色型色覚は, 53名 （10.9\%）であるが，中度以下と判定される二色 型色覚が 214 名 $(53.8 \%)$ と半数以上いた。

石原表による判定結果は表 4 である（分類不 明 4 名)。異常三色型色覚であるのに赤緑色 盲 (強度) と分類された者が534名 (80.0\%) い

表 2.TMC表による程度判定

\begin{tabular}{|c|c|c|}
\hline & 二色型色赏 (色亩) & 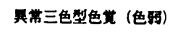 \\
\hline 弱度 & $7(1.8 \%)$ & $118(24.2 \%)$ \\
\hline 中等度 & $73(18.3 \%)$ & $207(42.4 \%)$ \\
\hline 䐈度 & $318(79.9 \%)$ & $163(33.4 \%)$ \\
\hline 台部 & $398(100 \%)$ & $488(100 \%)$ \\
\hline
\end{tabular}

表 3. 石原・大熊表による程度判定

\begin{tabular}{|c|c|c|}
\hline & 二色型色机（色高) & 基常三色型色党（色猗） \\
\hline 故度 & $6(1.5 \times)$ & $117(23.9 \times)$ \\
\hline 基度 & $27(6.8 \%)$ & $143(29.3 \times)$ \\
\hline 中度 & $181(45.5 \%)$ & $175(35.9 x)$ \\
\hline 㣀度 & $184(46.2 \%)$ & $53\left(\begin{array}{lll}1 & 0.9 & 9 x\end{array}\right)$ \\
\hline 合部 & 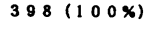 & $488(1000)$ \\
\hline
\end{tabular}


表 4. 国際版石原式色覚検查表による程度判定

\begin{tabular}{|c|c|c|}
\hline & 二色型色（色亩） & 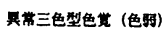 \\
\hline 歖废（色䀦） & $3(0,9 x)$ & $134(20.0 \%)$ \\
\hline 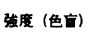 & $325(99.1 \%)$ & $534(80.0 \%)$ \\
\hline 合到 & $328\left(\begin{array}{llll}1 & 0 & 0 & 4\end{array}\right)$ & $668(1000)$ \\
\hline
\end{tabular}

表 5. TMC表と石原・大熊表の判定の比較

石原・大箸表

\begin{tabular}{|c|c|c|c|c|}
\hline & 期度 & 锃㡲 & 中度 & 强度 \\
\hline 而度 & 76 & 36 & 13 & 0 \\
\hline 中等度 & 34 & 84 & 127 & 34 \\
\hline 强度 & 11 & 54 & 221 & 200 \\
\hline
\end{tabular}

た。

表 5 は T MC 表と石原 ·大熊表との程度判定 の結果がどれくらい一致したかをみたものであ る。 $\mathrm{TMC}$ 表と石原・大熊表とが同じ判定結果 になった者は 439 名 $(49.5 \%)$ と半数に満たなか った。また，判定結果が極端に違う者（判定結 果が二段階以上違う者）は11.2\%あった。

\section{IV.考案}

仮性同色表の程度表によって適切な判定が出 来るかどうかは, いくつかの報告がある213)。 いずれも全体的に見ると，二色型色覚（いわゆ る色盲) では強度が多く, 異常三色型色覚（い わゆる色弱) では軽度が多い判定結果となって いるが, 症例の各々では二色型色覚でも軽度と 判定される者がある一方, 異常三色型色覚でも 強度と判定される者も少なくない。また, 今回 の検証と同様に二種類以上の表の判定が一致し ない場合も多い。

程度表は地色と図形の色との色差を使って作 られている。すなわち，TMC表では地色が黄 緑色, 左側の数字は彩度の高い橙色, 右側の数
字は彩度の低い橙色である。図 1 のように左の 数字の方が, 右の数字より色差が大きいので読 みやすいと考えられる。石原・大熊表は，第一 色盲と第二色盲のそれぞれの中性色で互いに補 色である赤紫色（図形）と黄緑色（地色）の彩 度三種類を使い程度分類している（図 2 )。こ の様に, 程度を判定する色差は各表ごとに違う ので表によって判定が異なるのは当然である。

ファンズワースのU. C. S. D ${ }^{11}$ は図の上の距 離と主観的な色の距離との差が比例するように 考案された模式図である（図 3 )。この模式図 で正常色覚, 第一異常, 第二異常を表し, その

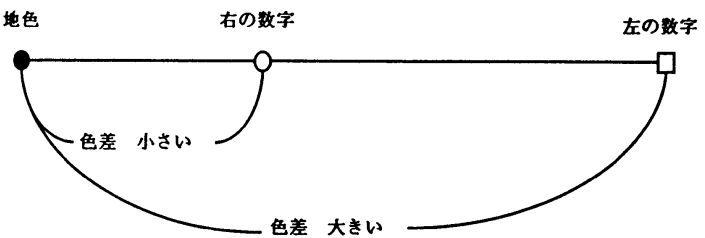

図 1.TMC表の程度表 左の数字の方が地色との色差が大きいので 読みやすい。

左右とも読めない：強度

左のみ読める : 中等度

左右とも読める：弱度

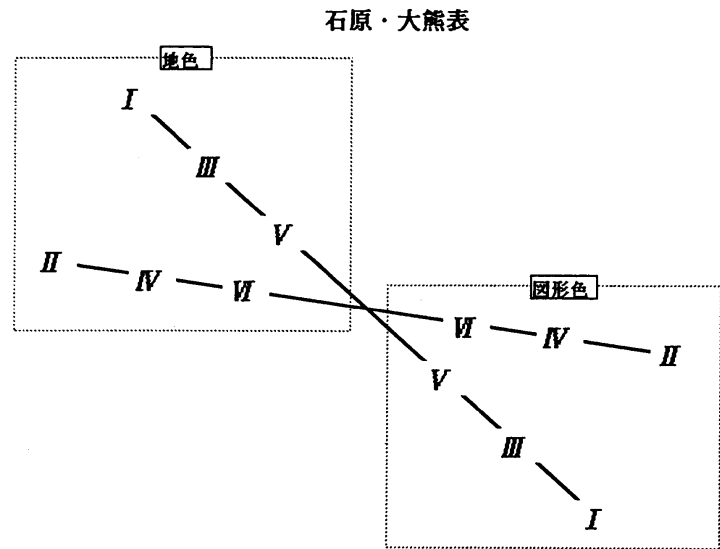

図 2 . 石原・大熊表

I，III，V表の色は第一色盲混同色線上にある。 II，IV，VI表の色は第二色盲混同色線上にある。 I $>$ III $>$ V 表, II $>I V>$ I 表の順に図形と地 色の色差が大きいので，どの色差まで正答で きるかによって程度を判定する。 


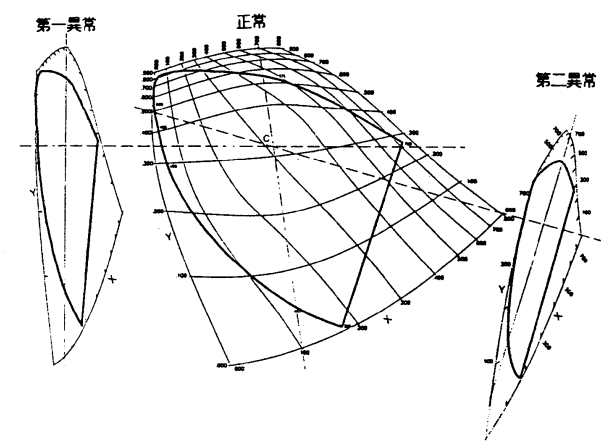

図 3. FarnsworthのUniform Chromaticity Scale Diagram (Farnsworth") より改変) 図上の距離と主観的な色の差が比例する。 色覚異常は正常色度図が一方向に圧縮された 形として表される。

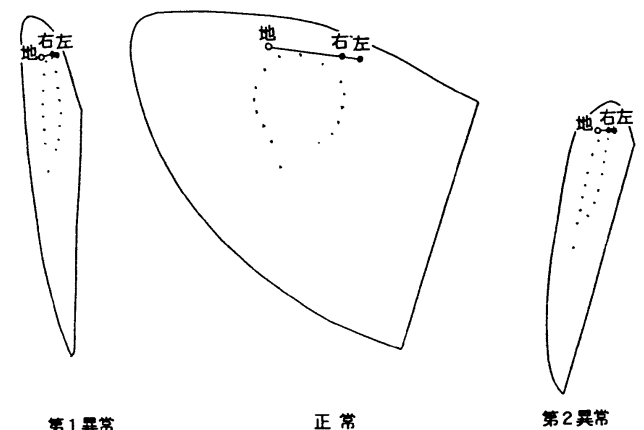

図 4.TMC表の程度表の色 色覚異常の色度図上では左の数字と右の数字 の色差がほとんどなくなる。
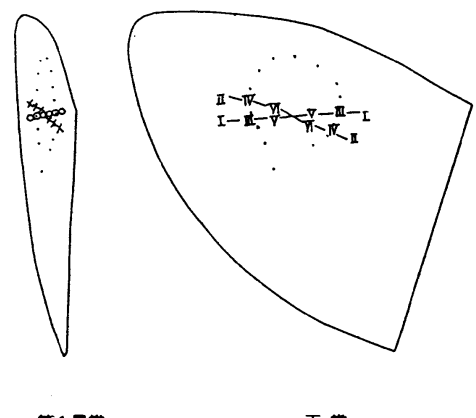

第 1 暴常

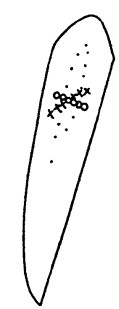

第2 贵常

図 5 . 石原・大熊表の色

色覚異常の色度図上では I, II, V 表も II, $\mathrm{IV}, \mathrm{VI}$ 表も色の差が非常に少なくなる。

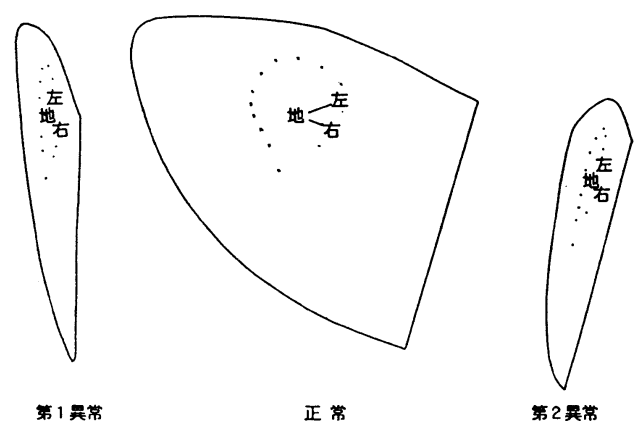

図 6. 石原表の分類表の色

色覚異常の色度図上では左の数字も右の数字 も地色との色差がほとんどなくなる。

上に今回使った程度表の色をプロットすると図 $4 ， 5 ， 6$ のようになる。正常色覚の模式図で は地色と図形との色は適度な距離を保っている が, 色覚異常の模式図では全ての色が非常に接 近して主観的な色の差はほとんど無くなってし まうことが解る。この図に描かれている色覚異 常の模式図はパネル D - 15テストが十分パスす る比較的軽い異常のものであるが，それでさえ 地色と図形の色の差はわずかである。故に，図 形が見えるかどうかは偶然に左右されるものと 思われる。

\section{V.まとめ}

仮性同色表の程度表によって色覚異常の程度 を判定することは，仮性同色表の種類によって 判定される程度が一致しない場合があり妥当で ない。これは，使用されている色が色覚異常者 の色感においては適当な色差ではないからであ る。従って，個々の症例について程度判定表の みで判定することは難しい。だから，色覚異常 の程度判定は仮性同色表のみで行うべきではな く，パネル D-15テストまたは，パネル D - 15 テストとランタンテストの組み合わせなどによ って判定するべきである ${ }^{4)}$ 。

\section{文献}

1) Farnsworth, D.: The F-M Test and Dichotomous Test for Color Vision. J. Opt. Soc. Amer. $33: 568-578,1943$. 
2）天野みゆき，鈴木永子，河合美重子，馬嶋昭 眼紀, $23 ： 170-175 ， 1972$. 生：色覚検査における各種程度判定方の比較. 日本視能訓練士協会誌, $20 ： 182-189,1992$.

3 ）馬嶋昭生, 栗屋忍: 色覚異常学童に於ける各 種色覚検查法 (Anomaloscope, 石原氏表, 大 質問 (滋賀医大 山出 新一) 熊氏表, 東京医大式, H-R-R表及びLanternTest）による成績の比較検討. 臨眼， 14 ： 439-451, 1960.

4 ）馬嶋昭生：先天色覚異常の診断基準について （III）ーパネル D-15とランタン併用による社 会適性判断基準（馬嶋試案）とその検討一。

1. 程度の分類を仮性同色表で行うべきではない ということですね。

\section{答弁}

1. 仮性同色表のみで程度の分類は行うべきでは ないと考えます。 